\title{
Knowledge of parents from urban and rural areas vs. prevention methods of hearing loss threats seen as challenges for public health
}

\author{
Maria Danuta Głowacka', Piotr Świdziński² , Anna Frankowska', Beata Bajurna', \\ Jerzy T. Marcinkowski ${ }^{3}$ Ewa Mojs ${ }^{4}$ \\ ${ }^{1}$ Department of Organisation and Management in Healthcare, Poznań University of Medical Sciences, Poland \\ ${ }^{2}$ Phoniatry and Audiology Department, Poznań University of Medical Sciences, Poland \\ ${ }^{3}$ Department of Social Medicine, Poznań University of Medical Sciences, Poland \\ ${ }^{4}$ Department of Clinical Psychology, Poznań University of Medical Sciences, Poland
}

Głowacka MD, Świdziński P, Frankowska A, Bajurna B, Marcinkowski JT, Mojs E. Knowledge of parents from urban and rural areas vs. prevention methods of hearing loss threats seen as challenges for public health. Ann Agric Environ Med. 2017; 24(2): 157-161. doi: 10.5604/12321966.1227650

\begin{abstract}
Introduction. Parents as day-to-day caregivers looking after their children's health and upbringing are crucial in the process of hearing loss prevention among the young. The aim of the study was to assess the parents' knowledge and awareness of hazards bringing about hearing loss, possibilities to prevent this, as well as their reaction in the case of problems of their children with hearing.

Material and methods. The research group comprised respondents (402 persons), medical or paramedical professionals. None of the surveyed was a doctor. $56 \%$ of the surveyed were inhabitants of large cities, $24 \%$ of small towns, and $20 \%$ of village, mostly located in the area of Greater Poland (Wielkopolska) (97\%). To perform the research a survey was devised. GSES scale was applied as an accessory tool.

Results. The subjects surveyed posses a great deal of knowledge concerning basic conditions that could adversely affect the hearing of children. Village inhabitants are half as afraid of hearing loss hazards as the inhabitants of large cities. More than $40 \%$ of the respondents claimed they do nothing to counteract their children's overexposure to noise. In $48.5 \%$ of cases, GPs had not drawn parents' attention to possible complications resulting from upper respiratory tract infections in children. Parents know where they should go to in case their children develop hearing problems or sudden hearing loss. Conclusions. Knowledge and awareness of factors that may trigger hearing loss is not synonymous with avoidance of the problem. Main components of hearing loss prevention among children and youths should be administrative actions, extensive education, and proper childcare at home.
\end{abstract}

\section{Key words}

hearing protection, children, public health

\section{INTRODUCTION}

Good hearing is a prerequisite for the proper development of speech in children. The youth with poor hearing have difficulties in interacting with their environment; they find it harder to concentrate and learn at school or college. That is why awareness of the hearing loss threat is so important, along with taking widespread preventive measures in health promotion.

The Polish national programme for the early detection of hearing disorders now covers almost $100 \%$ of all newborn children [1]. Early detection of hearing impairment - if properly treated and rehabilitated - creates opportunities for gaining the capacity to use intelligible speech [2]. In Poland, every year, almost 30,000 children are born with a hearing impairment [3]. With every subsequent year, the number of people suffering from hearing loss is growing [4]. A number of actions are being taken to carry out the screening also of preschool and school children. The most ambitious project of recent years was the one which comprised diagnosing of hearing loss among children from the lower grades of

Address for correspondence: Jerzy T. Marcinkowski, Department of Social Medicine, Poznań University of Medical Sciences, Poland

E-mail: jtmarcin@gmail.com

Received: 26 April 2013; accepted: 20 May 2015; first published on December, 2016 primary schools in rural areas. The results clearly show that there is a significant percentage of acquired hearing loss among primary school children who demonstrate the necessity to perform hearing screening tests at the later stages of children's development [5]. The model of children's auditory care should therefore include pre-school children, as well as those in primary schools, secondary schools and high schools [6]. According to the American Speech-LanguageHearing Association (ASHA), the loss of hearing acquired by children is caused mainly by:

- ear infections (very common in children);

- ototoxic medicine;

- infectious diseases (measles, chicken pox, mumps);

- head injuries;

- noise exposure;

- complications resulting from renal diseases, diabetes, heart diseases, neurological diseases (meningitis, encephalitis), allergies, etc. [2, 7].

According to preliminary research conducted in Poland, among younger school children [8] one child in five has hearing problems, mainly following diseases of the middle ear, which might lead to permanent sensorineural hearing loss $[2,4,9]$. Noise exposure causes permanent or temporary hearing impairments $[2,10]$ and is the most frequent cause 
of permanent hearing impairments acquired by children $[10,11,12]$. The sources of exposure in the perinatal period are e.g., incubators, and while in infancy-sound-producing toys [10]. At a later stage of a child's development, the factors most frequently listed in the literature include loud music $[10,13,14]$ and the sound of firecrackers and fireworks [10, 15]. The long-standing influence of environmental noise, i.e. that of school, means of transport, etc., also has a negative effect on hearing $[16,17]$. The risk of permanent hearing loss due to noise is proportional to the degree of exceeding noise standards [18]. Although organising hearing screening is an important issue, it is secondary in the case of acquired hearing loss. Following the principle of 'prevention is better than cure', an appropriate system of auditory education for parents seems necessary, i.e. persons who are responsible for the protection of health and the children themselves. The problem is becoming more and more pressing, not only in Poland, which is why the World Health Organization (WHO) and its regional office in Europe have developed a plan, the Children's Environment and Health Action Plan for Europe (CEHAPE) that assumes the protection of children and adolescents against the harmful effects of excessive noise on health [17]. Children and adolescents in schools have very little awareness of the lurking environmental dangers that can lead to hearing loss $[12,19]$. Is the environment of adults, in which the child is present every day, aware of these dangers?

Objective. The aim of this study was to evaluate both the knowledge and awareness of parents regarding hearing loss threat, the means to counteract the most common threats of hearing loss according to interviewed parents, and their reaction in the case of problems of their children with hearing.

\section{MATERIALS AND METHOD}

The surveyed group consisted of adults between the ages of $24-60$ (Fig. 1), who had children aged from 6 months to 20 years. All the respondents practised a medical or paramedical profession (physiotherapists, nurses, midwives, hearing aid technicians, opticians, health promoters), but they were not doctors. Of the respondents, 359 were women $(89.3 \%)$ and 43 - men (10.7\%).

The respondents came from large cities (56\%), from small towns (24\%) and villages (20\%) mainly of the Greater Poland (Wielkopolska) region (97\%). The respondents' economic

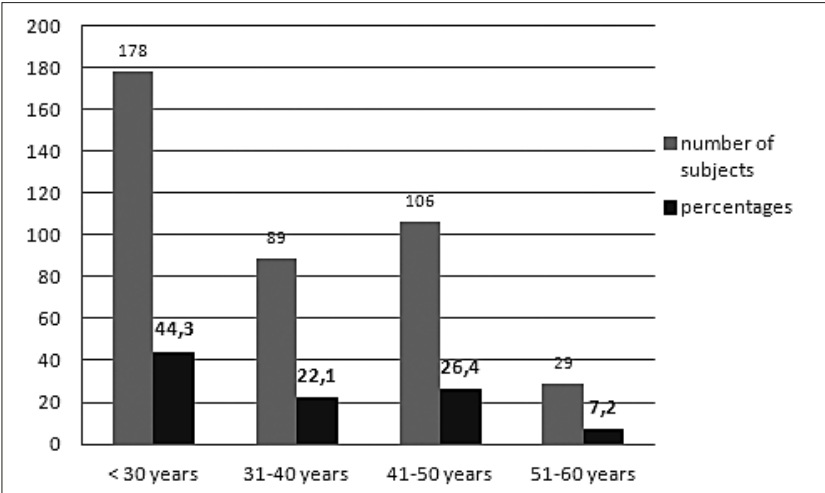

Figure 1. Numeric and percentage values in the age groups of respondents. Source: own study status was, respectively, high (3.2\%), average (82.4\%) and low (14.4\%). $41 \%$ of the respondents have multi-children families, while $59 \%$ - one-child families.

Surveys were conducted among the students of the Medical University in Poznań during 2011-2013. The selection of respondents was intentional: the persons selected practised a medical or paramedical profession. Representativeness of the sample was ensured (random selection of individuals for the sample).

A survey consisting of 15 questions was designed to investigate the knowledge of the conditions that may be harmful to hearing in children and youth, and to verify the knowledge and ways of preventing them. The survey was to be completed by parents and caregivers. It was supported by the GSES psychological assessment by Schwarzer, Jerusalem and Juczyński [20] evaluating self-efficacy in difficult situations.

The survey developed and used in the study included questions testing specific knowledge of the types of threats, questions about the reaction of the parent to such a risk, questions about preventive measures and responses to the specific situation of hearing loss in their child, along with questions about demographic and economic status of respondents.

A statistical analysis was performed with chi-square test, Fisher's test, using the database created in MS Excel 2007.

\section{RESULTS}

Knowledge of hearing risk factors. Parents and caregivers' answers to the general question about the awareness of the risks which may result in the loss or deterioration of hearing in children was that they were aware of the problem (almost $94 \%$ ), while only $6 \%$ admitted that they were not aware of it. No statistically significant differences were identified in terms of place of residence. The strongest awareness was recorded in the age group of $41-50$ years $(96 \%)$, while the lowest in the group 51-60 years (90\%). Frequency of response 'I am not aware of the hearing loss risk' among parents with one child was more than three times higher than among those with more children (Fisher's exact test: $\mathrm{p}=0.020$ ).

Knowledge of the existence of threats likely to cause hearing loss translates into concern about the risk factors that could cause acquired hearing loss in children. As many as $93 \%$ of parents fear that the risks listed in the hearing loss survey could affect their children, with the risk being excessive noise, ototoxic drugs, complications resulting from colds and flu, complications resulting from infectious diseases, systemic diseases, head injuries and falls. Among rural residents, the fear is more than $50 \%$ lower than among inhabitants of large cities (Chi-square test: $\mathrm{p}=0.017$ ).

The above-mentioned factors that might pose a threat to hearing were placed in the table and the respondents were asked to assess them in terms of the greatest harmfulness to hearing, in their opinion in general for all children, and their children in particular. The scale of assessment: from 1 (the most significant factor) to 6 (the least significant factor) (Fig. 2.)

In the respondents' opinions, as regards their own children, the most significant were the following factors: first of all: noise, head injuries, effect of ototoxic drugs, complications resulting from infections, complications resulting from infectious diseases and complications resulting from systemic diseases. 


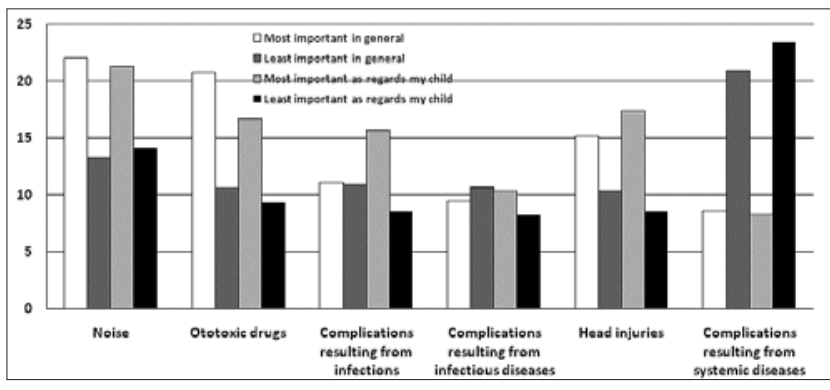

Figure 2. Percentage of most significant and least significant responses in assessing risks in general and in respondents' own child.

Source: own study.

Parents assessed the extent of the noise-related risk associated with the place of residence of their children. Table 1 shows the obtained results (in \%) on a three-point rating scale: high risk, medium risk, no risk for my child.

Table 1. Noise risk related to place of children's residence as assessed by their parents on a three-point rating scale

\begin{tabular}{lccc}
\hline Place/method & $\begin{array}{c}\text { High risk } \\
\%\end{array}$ & $\begin{array}{c}\text { Medium risk } \\
\%\end{array}$ & $\begin{array}{c}\text { No risk } \\
\%\end{array}$ \\
\hline a) school breaks & 31.1 & 51.5 & 17.4 \\
\hline b) pre-school & 7.7 & 52.7 & 39.6 \\
\hline c) at home, listening to loud music & 43.5 & 44.8 & 11.7 \\
\hline d) listening to mp3, mp4 players & 65.2 & 23.6 & 11.2 \\
\hline e) at a concert & 54.2 & 26.1 & 19.7 \\
\hline f) at a disco & 62.4 & 18.2 & 19.4 \\
\hline g) at a party at friends' place & 11.2 & 55 & 33.8 \\
\hline h) at a playground & 2 & 42.3 & 55.7 \\
\hline i) at a cinema & 8.2 & 52.2 & 39.6 \\
\hline j) in a street (street noise) & 10.2 & 63.4 & 26.4 \\
\hline k) other (trains, machines, renovations) & $\mathrm{n}=2$ & $\mathrm{n}=5$ & $\mathrm{n}=0$
\end{tabular}

Source: own study

Parents whose children attend schools often argue that the noise threat in this environment is mainly high (31\%) and medium (52\%). Responses of parents of children who live in big cities and rural areas do not differ in any significant way. Parents of only children believe that the noise threat at school is smaller than those who have several children. (Chi-square $=0.024$ ) .

According to the parents whose children attend pre-schools, the older they get, the frequency of responses indicating a high and medium risk of noise decreases, while the response 'there is no such risk' increases $(\mathrm{p}=0.001)$. However, the response 'no risk' among those who have more children is more than one third higher than among parents with one child (Chi-square $p=0.033$ ). There were no differences in the views of residents of urban and rural areas.

In $13 \%$ of cases, women believe that listening to music on $\mathrm{mp} 3 / \mathrm{mp} 4$ players (using headphones) does not cause hearing loss in their children. $24 \%$ of them think that the risk is medium, and $63 \%$ - that it is a very significant threat. Men think that the risk is high (86\%), while $14 \%$ of them think that the risk is medium $(\mathrm{p}=0.005) .70 \%$ of people from urban areas and $60 \%$ from rural area think that the risk is high.

$54 \%$ of the respondents believe that their children are very vulnerable to hearing loss at concerts. The frequency of the 'high risk' responses among the inhabitants of rural areas and small towns is by $25 \%$ smaller than among the inhabitants of large cities ( $\mathrm{p}=0.016)$. The risk of hearing loss at discos is rated at the same level (63\%) in all age groups and in groups of men and women, as well as among inhabitants of rural areas and cities. Inhabitants of cities and villages assessed that the noise in cinemas entails an average degree of risk. Traffic noise is rated as a high risk only by $10 \%$ of respondents.

Preventing the risk of hearing loss. Parents know their children's hearing status. Approximately $1 \%$ of children of the surveyed have permanent hearing problems, while $15 \%$ have temporary problems; of these, the smallest problems occur in the case of children of the youngest parents.

The question: 'Do you take any preventive measures to reduce your child's exposure to excessive noise?' elicited a somewhat surprising answer: $59.5 \%$ of parents answered positively, but more than $40 \%$ of parents ignore this problem, as evidenced by the number of negative answers. Differences on the border of statistical error $(\mathrm{p}=0.06)$ occurred between the positive responses of city residents (64\%) and rural residents (54\%). The frequency of taking preventive actions among women was 1.5 times higher than among men $(p=0,020)$. There was a large disparity between the age groups $(\mathrm{p}=0.001)$. Preventive measures were most frequently taken in the groups of people aged 31 - 50 years, which correlates with the number of children per family. The frequency of negative responses among parents of one child was nearly 1.5 times higher than among those with more children (Fisher's exact test: $\mathrm{p}=0.006$ ).

By being asked open questions, the parents were to indicate effective methods of counteracting the influence of noise on their children. Almost $78 \%$ of parents (who answered the question) would prohibit or restrict listening to loud music or using earphones with MP3 players, and staying in noisy places. Urban dwellers made up over $50 \%$ of this group and inhabitants of small towns and rural residents less than $28 \% .12 \%$ of parents would prohibit listening to loud $\mathrm{TV}$, of whom $8 \%$ were rural and small town residents, and only $4 \%$ parents from large cities. Other proposals, such as education concerning effects of excessive exposure to noise (and as a consequence, avoiding situations posing a threat), and spending more time in nature were suggested by $10 \%$ of parents.

Most people would know where to go if their child started to experience hearing problems (81\%), including an appointment with a laryngologist $-53.6 \%$, going to a hospital - $10 \%$, to a general practitioner $-18.2 \%$. However, as many as $19 \%$ of people with a medical or paramedical profession would not know where to go. There are no statistically significant differences between the responses of inhabitants of cities and villages, men and women $(\mathrm{p}=0.335)$.

The parents have also revealed - quite surprisingly - that in the case of infections of the upper respiratory tract, throat, or larynx, in $48.5 \%$ of cases attending physicians never pay attention to the potential complications related to hearing, in $37.8 \%$ - they do so 'sometimes', in $10.2 \%$ - 'often', and 'always' in $3.5 \%$ of cases.

Responding to an emergency situation related to loss of hearing. The question 'What would you do first if your child suddenly lost its hearing?' produced the following answers: $82.7 \%$ of respondents said - regardless of their 
place of residence - that they would go to a private specialist as soon as possible ('at whatever cost'), $8.7 \%$ would go to a specialist and sign up for an appointment, $3.2 \%$ would go to a hospital, the same number of respondents would start to look for help by talking to friends and looking for information on the Internet, while approximately $2 \%$ would get into panic, not knowing what to do.

The level of efficiency in coping with difficult situations was assessed on the Generalized Self Efficacy Scale (GSES), identifying the percentage value of low results (state 1-4), medium (state 5-6) and high (state 7-10). The temporary Polish standards (20) are provided in parentheses (Tab. 2). The test results indicate very good self-esteem of the respondents. There is no statistically significant correlation between the inhabitants of rural areas and cities, respondents' age and gender, and the resulting scale of the GSES. With the increase in the results of GSES category, one witnesses an increase in the frequency of positive responses to the question about taking preventive measures related to the exposure to noise (Chi-square test: $\mathrm{p}=0.048)$.

Table 2. Numeric and percentage values of GSES average results for $\mathrm{n}=402$ people

\begin{tabular}{lcc}
\hline GSES results by category & $\mathrm{n}$ & Percent \\
\hline low & 15 & 3.7 \\
\hline average & 117 & 29.1 \\
\hline high & 270 & 67.2 \\
\hline
\end{tabular}

Source: own study

\section{DISCUSSION}

Among the respondents from the milieu of health protection, living in rural areas and cities, analysis was carried out of their knowledge and awareness of the risks of hearing loss in their own children, as well as of ways to prevent the most common threats. The dominant feature in the selected group of people was the high rate level of self-assessment on the GSES scale. The respondents demonstrated awareness of the existence of, as well as concern about the indicated factors that adversely affect hearing.

Because of the respondents' occupation, one would expect (regardless of the place of residence) that their knowledge of the lurking dangers would go hand-in-hand with strong awareness of the hearing loss risk to which their children are exposed, and with intensive activity of the surveyed parents related to preventing the effects of such a risk. The above results show a certain degree of disdain for this problem.

Most often, the problem of acquired hearing disorders focuses on noise and its effects on children and adolescents, which may manifest themselves not only in the loss of hearing, but also in somatic and cognitive disorders [10, 17, 21]. A large percentage of respondents (over 40\%) replied that they do not do anything to prevent the exposure of their children to excessive noise. The respondents living in cities expressed a greater fear associated with various types of hazards which may affect the hearing of their children than those living in rural areas. The respondents predominantly feared noise sources to which their children are exposed during leisure time, listening to MP3 players (using headphones), going to concerts, discos, and listening to loud music at home (these data coincide with worldwide reports) [12, 13, 21]. Elderly parents and those having large families were more attentive with respect to the consequences of these threats than younger parents and those with only one child. In the opinion of respondents, the majority of them were aware of their children's hearing status, and knew what they should do in the case their children develop hearing problems or sudden hearing loss.

A large responsibility in the context of threats of hearing loss falls on doctors. Specialists in this field, however, are of no help either. As can be seen from the presented study, very few parents pay attention to the possible complications associated with hearing, even in the case of very frequently encountered threats, such as infections of the upper respiratory tract (possibility of temporary or permanent hearing loss).

Numerous scientific and popular science papers are published to describe in detail, but in a generally understandable way, the factors contributing to hearing impairment $[9,10,21]$. Among the prevention programmes and public awareness campaigns can be identified those organized by local government institutions and State government institutions, research institutes, foundations, and finally - companies that produce hearing aids [22]. New technologies and the Internet have become a major source of knowledge of the subject [12]. In Poland, however, campaigns of hearing tests are far more numerous than educational campaigns. The proportion is clearly unequal. The world of science is aware of this and every day it tries to highlight the problem and launch a number of campaigns [23]. Despite many attempts to remedy this situation by experts on the subject, the reality is still unsatisfactory: the number of people with acquired hearing loss is on the increase $[4,5,12]$. There is still a lack of general social awareness in Poland, not to mention implementing preventive measures in everyday life. By implementing the policy of reducing the gap between Eastern and Western Europe ('East-West Health Gap') [24] in the field of detection of hearing disorders in children, we have nothing to be ashamed of. But we fare much worse when it comes to education.

The new concept of public health emphasizes that it is important to scientifically recognize health needs, and to initiate and organize coordinated efforts of government institutions, local authorities and non-governmental organizations in order to achieve the desired health standards [25]. The main elements of the system preventing the threats of hearing loss in children and adolescents should be the administrative activities, campaigns in the mass media, as well as the proper care of children at home.

\section{CONCLUSIONS}

1. The subjects surveyed possess a great deal of knowledge concerning basic conditions that could adversely affect the hearing of children.

2. Respondents and healthcare professionals working in medical and paramedical professions, living in rural and urban areas, do not always take preventive actions to counteract hearing disorders.

3. According to the respondents, noise is the key factor that may affect hearing loss in children.

4. Parents are aware of whom they should turn to in the case of a child's difficulties with hearing. 
5. Health workers responsible for the hearing status of children and youth at the level of general treatment do not always pay attention to the basic guidelines of hearing hygiene.

6. Coordinated and long-standing education aimed at strengthen the awareness of the causes of hearing loss is the most important way to prevent and counteract the presented threat.

\section{REFERENCES}

1. Morton CC, Nance WE. Newborn Hearing Screening - A Silent Revolution. N Engl J Med. 2006; 354: 2151-2164.

2. Pruszewicz A, Obrębowski A. (ed.): Audiologia kliniczna- zarys. Wyd.4. Wydawnictwo Uniwersytetu Medycznego, Poznań, 2010: 355-366 (in Polish).

3. Own study based on: Ludność - bilans opracowany w oparciu o wyniki NSP 2011. Rocznik statystyczny 2011, http://www.wosp.org $\mathrm{pl} /$ medycyna/nasze_programy/badania_sluchu.(access:2013.04.12), Wróbel M, Podsumowanie działalności I, II i III poziomu referencyjnego. Uszko. 2011; 17: 11-17 (in Polish).

4. Skarżyński H, Davis A, Piotrowska A, Stephan K. European Consensus on Hearing Screening in School- age Children. 10th EFAS Congress 2011, Warsaw, Poland.

5. Skarżyński H, Kochanek K. Badania przesiewowe słuchu u dzieci. September 2009: www.gazetalekarska.pl (access:2013.04.12) (in Polish)

6. Głowacka MD, Świdziński P, Mojs E, Frankowska A. Projekt modelu opieki zdrowotnej nad dzieckiem niedosłyszącym. A model of healthcare for children with hearing disorders. Ann Acad Med Stetin. 2009: 55(3): 90-95 (in Polish).

7. http://www.asha.org/public/hearing/Acquired-Hearing-Loss/ (access:2013.04.12).

8. Skarżyński PH, Kochanek K, Ludwikowski M, Zapert A, Ganc M, Senderski A, Skarżyński H, Piłka A, Piotrowska A, Krol B. Hearing screening in 6th grade children in primary schools in Warsaw. 10th EFAS Congress 2011, Warsaw, Poland.

9. Richard JH, Bale JF, White KR. Sensorineural hearing loss in children. The Lancet. 2005; 365: 883-885.

10. Sułkowski WJ. Uszkodzenia słuchu spowodowane hałasem u dzieci i młodzieży: przyczyny i prewencja. Noise-induced hearing loss in children and youth: causes and prevention. Med Pracy. 2009; 60(6): 513-517 (in Polish).
11. Daniel E. Noise and Hearing Loss: a Review. J School Health. 2007; 77(5): 225-231.

12. Chung JH, Des Roches CM, Meunier J, Eavey RD. Evaluation of NoiseInduced Hearing Loss in Young People Using a Web-Based Survey Technique. Pediatrics.2005; 115(4): 861 -867.

13. Vogel H, Verschuure H, van der Ploeg CPB, Brug J, Raat H. Adolescents and MP3 Players: Too Many Risks, Too Few Precautions. Pediatrics. 2009; 120(6): $953-958$.

14. Mercier V, Luy D, Hohmann BW. The sound exposure of the audience at a music festival. Noise Health. 2003; 5(19): 51-58.

15. Regal S, Eviatar E, Lapinsky J, Shlamkowitch N, Kessler A. Inner ear damage in children due to noise exposure from toy cap pistols and firecrackers: a retrospective review of 53 cases. Noise Health. 2003; 5(18): 13-18.

16. Hanke W (ed). Plan dotyczacy środowiska i zdrowia dzieci (CEHAPE). Ministerstwo Zdrowia, Ministerstwo Środowiska WHO-Polska Publishers. 2009; 86-91 (in Polish).

17. Children and noise. Children's Health and the Environment WHO Training Package for the Health Sector World Health Organization. 2013. www.who.int/ceh (access: 2013.04.12).

18. Rozporządzenie Ministra Środowiska z dnia 1 października 2012 r. zmieniające rozporządzenie w sprawie dopuszczalnych poziomów hałasu w środowisku. Na podstawie art. 113 ust. 1 ustawy z dnia 27 kwietnia 2001 r. - Prawo ochrony środowiska Dz. U. z 2008 r. Nr 25, poz. 150, z późn. zm., Dz. U. z dnia 8 października 2012 r. Poz. 1109 (in Polish).

19. http://www.slaboslyszacy.pl/info,252.html (access:2013.04.12) (in Polish).

20. Juczyński Z. Narzędzia pomiaru w promocji i psychologii zdrowia, Pracownia Testów Psychologicznych Warszawa. Poland. Część B:96.

21. Henderson E, Testa MA, Hartnick Ch. Prevalence of Noise-Induced Hearing-Threshold Shifts and Hearing Loss Among US Youths. Pediatrics. 2011; 127(1): 39-46.

22. Own study based on: www.noisyplanet.nidcd.nih.gov/, http://www. earbud.org/resources/about_us.html, May is better hearing and speech month http://www.asha.org/bhsm/,http://www.actiononhearingloss. org.uk/loudmusic.aspx? utm source=Offline\&utm medium=Offline\&utm_campaign=Loud-Music-URL, http://www. hear-the-world.com/, http://idainstitute.com/ideas_worth_hearing/ about_the_ideas/\#.RHekl0qrRaU (access:2013.04.12).

23. Own study based on: http://www.polskieradio.pl/92, www.psps.pl, www.slyszymy.pl, www.kampaniespoleczne.pl, (access:2013.04.12).

24. Zatoński W. The East-West Health Gap in Europe-what are the causes? Eu J Pub Health. 2007; 17(2): 121

25. Wysocki MJ, Miller M. Paradygmat Lalonde’a, Światowa Organizacja Zdrowia i Nowe Zdrowie Publiczne. Przegl Epidem. 2003; 57: 505-512 (in Polish). 